\title{
Correlation of Disease Knowledge with Adherence to Drug Therapy, Blood Sugar Levels and Complications Associated with Disease among Type 2 Diabetic Patients
}

\author{
Amruta Sumedh Mandpe*, Vijaya A Pandit, Jayshree S Dawane and Hardik R Patel \\ Bharati Vidyapeeth Medical College, Pune, India \\ "Corresponding author: Amruta Sumedh Mandpe, Bharati Vidyapeeth Medical College, Satara Road, Pune- 411043, India, Tel: +918600036347; E-mail: \\ amruta.mandpe@yahoo.in
}

Rec date: Apr 01, 2014, Acc date: May12, 2014, Pub date: May 16, 2014

Copyright: @ 2014 Mandpe AS, et al. This is an open-access article distributed under the terms of the Creative Commons Attribution License, which permits unrestricted use, distribution, and reproduction in any medium, provided the original author and source are credited.

\begin{abstract}
Background: Low adherence to medication is a growing concern, seriously undercutting the benefits of current medical care. Present study was plannedon the assumption that knowledge regarding diabetes might be important contributory factor affecting adherence to the treatment regimen, which is crucial in glycemic control \&complications related to the disease.
\end{abstract}

Objectives: To investigate any association of knowledge withmedication adherence, Blood sugar level\& incidence of associated complications in patients with type 2 diabetes mellitus.

Material and method: A cross-sectional study was conducted among 100 adult patients with type 2 diabetes mellitus attending the Diabetes OPD, Bharatividyapeeth Deemed University, medical college, Pune. A questionnaire including Michigan Diabetes Knowledge Test and Morisky Medication Adherence Scale was used. Patients' medical records were reviewed for Blood Sugar control and occurrence of related complication like arrhythmias, nephropathy, and retinopathy.

Results: Analysis of observation shows that $45 \%$ of patients had adequate knowledge about diabetes. Out of these $45 \%$ of patients, $93.33 \%(42 / 45)$ of patients were adherent to drug therapy $(p<0.001), 86.66 \%(39 / 45)$ of patients had BSL Fasting $<100 \mathrm{mg} / \mathrm{dl}(\mathrm{p}<0.001), 84.44 \%(38 / 45)$ of patients had BSL PP<135 mg/dl $(p<0.001)$ and only $2.22 \%(1 / 45)$ of patients had history of diabetes related complication.

Conclusion: Diabetes knowledge was significantly correlated with better medication adherences, good glycemic control and low incidence of disease related complications.

Keywords: Knowledge; Adherence; Blood sugar levels; Type 2 diabetes

\section{Introduction}

Diabetes mellitus, or simply diabetes, is a group of metabolic diseases in which a person has high blood sugar [1]. This high blood sugar produces the classical symptoms of polyuria (frequent urination), polydipsia (increased thirst), and polyphagia (increased hunger).

Diabetes is a complex chronic illness which requires life-long management. All forms of diabetes increase the risk of long-term complications. These typically develop after many years (10-20). The major long-term complications relate to damage to blood vessels [2].

The main "macrovascular" diseases (related to atherosclerosis of larger arteries) are ischemic heart disease (angina and myocardial infarction), stroke, and peripheral vascular disease. Diabetes also damages the capillaries (causes microangiopathy) [3] which lead to diabetic retinopathy, diabetic neuropathy, and diabetic nephropathy.

Management concentrates on keeping blood sugar levels as close to normal ("euglycemia") as possible, without causing hypoglycemia. This can usually be accomplished with diet, exercise, use as well as adherence to the appropriate medications.

It is a growing world-wide epidemic with the number of people with diabetes estimated to reach 330 million by 2030 [4]. Over 30 million have now been diagnosed with diabetes in India. The CPR (Crude prevalence rate) in the urban areas of India is thought to be 9 per cent. In rural areas, the prevalence is approximately 3 per cent of the total population [5]. India is emerging as the 'diabetes capital' of the world. Every 10th Indian suffers with either Coronary Artery Disease (CAD) or diabetes by 2030 [6].

Non-adherence to medication is very common in the management chronic illness and diabetes mellitus is one amongst them. Some studies have shown that non-adherence increases the relative risk of myocardial infarction, coronary heart disease, kidney disease, stroke etc. [7].

Some patients are not aware of the chronic nature of their condition and therefore believe a short term treatment will totally cure them of the disease. Patient's poor understanding of the disease, poor understanding of proper use of the medications as well as the benefits and risks of the treatment have been identified as some of the patient related barriers to adherence [8]. Diabetes self-management education 
Citation: Mandpe AS, Pandit VA, Dawane JS, Patel HR (2014) Correlation of Disease Knowledge with Adherence to Drug Therapy, Blood Sugar Levels and Complications Associated with Disease among Type 2 Diabetic Patients. J Diabetes Metab 5: 369. doi: $10.4172 / 2155-6156.1000369$

Page 2 of 5

is a critical element of care for all people with diabetes and is necessary in order to improve patient outcome [9].

A relationship between non-adherence and mortality has also been reported. Medication non-adherence is particularly common among patients with type 2 diabetes and inadequate adherence compromises treatment effectiveness \& safety, leading to increased morbidity and mortality with, considerable direct and indirect cost to the health-care system [10-12]. Many variables pertaining to doctor and/or patients have been studied to predict adherence to treatment. But neither socio-economic nor pathology-related factors consistently predict adherence to the treatment [13]. Positive health outcomes and lower mortality among patients with diabetes have been associated with good adherence compared with those patients with poor adherence [14-16].

To date, few studies have assessed both patient diabetes knowledge and medication adherence in type 2 diabetes, and there is paucity of data exploring the association between medication adherence and diabetes knowledge with glycemic control [17].

Therefore, the present study aimed to assess: (1) the general level of diabetes knowledge and medication adherence in patients with type 2 diabetes; (2) the correlation between demographic characteristics (age, gender and educational level) with both general diabetes knowledge and medication adherence; and (3) the associations between patient knowledge, medication adherence, glycemic control \& incidence of complications associated with diabetes.

\section{Materials and Method}

A cross-sectional study was conducted in the Diabetes Clinic of tertiary health care hospital; Bharati Vidyapeeth deemed university medical college \& hospital, Pune. Before starting the study approval from the Institutional Ethical Committee was taken. A sample of 100 type 2 diabetes outpatients was included in the study.

The inclusion criteria was

(1) All Patients diagnosed with type 2 diabetes and above 18 years of age

(2) Patients willing to participate, who have given written consent to participate in the study

The exclusion criteria was

(1) Patients not willing to give written informed consent.

(2) Pregnant woman

Written informed consent was also obtained from the patients prior to the commencement of the study \& data was collected.

\section{Procedure}

Data collection was done by face-to-face interviews from the patients and case paper analysis by principal investigator. And demographic details of patients which included age, gender, education level, addiction, etc. were obtained.

Information about hypoglycemic medication, BSL within last 8 days, occurrence of related complication; was obtained from case paper analysis.

\section{Data collection form}

Data were collected using a set of questionnaires including previously validated questionnaire among diabetes type 2 who attended the Diabetes Outpatient Clinic [18,19].

Three main variables, (1) general diabetes knowledge of the patients, (2) medication adherence, and (3) blood sugar levels were selected to be measured in addition to socio-demographic and diabetes related data.

\section{Diabetes knowledge}

The brief diabetes knowledge test developed by the Michigan Diabetes Research and Training Center (MDRTC) known as Michigan diabetes knowledge test (MDKT) [18] was used to assess the general knowledge of diabetes.

\section{Medication adherence}

Morisky scale, also known as Morisky Medication Adherence Scale (MMAS) [19] was used for the assessment of medication adherence.

\section{Glycemic control}

The current study used blood sugar levels as an indicator of glycemic control among patients.

Blood sugar levels fasting $>100 \mathrm{mg} / \mathrm{dl}$ and post prandial $>135 \mathrm{mg} / \mathrm{dl}$ are indicative of poorly controlled glycemic levels, and thus poor diabetes management [20].

\section{Statistical analysis}

Descriptive statistics was used to describe demographic and disease characteristics of the patients and their diabetes knowledge. Percentages and frequencies were used for the categorical variables; Chisquare (and Fisher's exact) test was used to identify relationship between knowledge, adherence, blood sugar levels and incidence of diabetes related complications. All statistical analyses were performed using SPSS version 17.0. The significance level was set at $\mathrm{P}<0.05$.

\section{Results}

\section{Demographic and diabetes related data}

The mean age of the patients was 57.43 years (SD 8.50105), ranging from 40 to 80 years (27\% from $40-50$ yrs.; $36 \%$ from $51-60$ years; $29 \%$ $61-70$ years and $8 \%$ of patients were above 70 years of age), with $54 \%$ males and $46 \%$ females. The $62 \%$ of patients had secondary level of education and above (Table 1).

\section{Patients' knowledge}

Patient's knowledge about diabetes was adequate as the educational level is increased $(\mathrm{P}<0.001)$. There was no significant relationship between age $(\mathrm{p}<0.127)$ and gender $(\mathrm{P}<0.161)$ of patient with knowledge about diabetes (Table 1).

\section{Medication adherence}

Patients with higher educational level had better medication adherence $(p<0.001)$. There was no significant relationship between 
Citation: Mandpe AS, Pandit VA, Dawane JS, Patel HR (2014) Correlation of Disease Knowledge with Adherence to Drug Therapy, Blood Sugar Levels and Complications Associated with Disease among Type 2 Diabetic Patients. J Diabetes Metab 5: 369 . doi: $10.4172 / 2155-6156.1000369$

Page 3 of 5

age $(\mathrm{p}<0.127)$ and gender $(\mathrm{P}<0.385)$ of patient with medication adherence (Table 1).

\begin{tabular}{|l|l|l|l|l|l|l|l|}
\hline Variables & $\begin{array}{l}\text { Freq } \\
\text { uenc } \\
\mathbf{y} \\
\mathbf{n}\end{array}$ & $\begin{array}{l}\text { Adequa } \\
\text { te } \\
\text { knowle } \\
\text { dge } \\
\mathbf{n}\end{array}$ & $\begin{array}{l}\text { Inadequ } \\
\text { ate } \\
\text { knowle } \\
\text { dge } \\
\mathbf{n}\end{array}$ & $\begin{array}{l}\mathbf{P} \\
\text { value }\end{array}$ & $\begin{array}{l}\text { Better } \\
\text { adheren } \\
\mathbf{c e} \\
\mathbf{n}\end{array}$ & $\begin{array}{l}\text { Poor } \\
\text { Adhere } \\
\text { nce } \\
\mathbf{n}\end{array}$ & $\begin{array}{l}\mathbf{P} \\
\text { value }\end{array}$ \\
\hline Age & & & & 0.127 & & & 0.127 \\
\hline $40-50$ yrs. & 27 & 17 & 10 & & 17 & 10 & \\
\hline $51-60$ yrs. & 36 & 12 & 24 & & 12 & 24 & \\
\hline $61-70$ yrs. & 29 & 13 & 16 & & 14 & 15 & \\
\hline$>70$ yrs. & 8 & 3 & 5 & & 3 & 5 & \\
\hline Gender & & & & 0.161 & & & 0.385 \\
\hline Male & 54 & 28 & 26 & & 27 & 27 & \\
\hline Female & 46 & 17 & 29 & & 19 & 27 & \\
\hline $\begin{array}{l}\text { Educatio } \\
\mathbf{n}\end{array}$ & & & & $<0.00$ & & & $<0.00$ \\
\hline No formal & 12 & 3 & 9 & & 4 & 8 & \\
\hline Primary & 26 & 3 & 23 & & 3 & 23 & \\
\hline $\begin{array}{l}\text { Secondar } \\
\mathrm{y}\end{array}$ & 57 & 34 & 23 & & 36 & 21 & \\
\hline $\begin{array}{l}\text { Graduatio } \\
\mathrm{n}\end{array}$ & 4 & 4 & 0 & & 3 & 1 & \\
\hline $\begin{array}{l}\text { Post- } \\
\text { graduatio } \\
\mathrm{n}\end{array}$ & 1 & 1 & 0 & & 0 & 1 & \\
\hline
\end{tabular}

Table 1: Correlation between demographic variables with diabetes knowledge and adherence to drug therapy $\left({ }^{*} p<0.01\right.$ difference statistically significant, ${ }^{* *} \mathrm{P}<0.001$ difference statistically highly significant). $n=$ number of patients

\section{Glycemic control}

BSL values were significantly lower in patients with higher level of education comparing with those patients with lower educational level $(\mathrm{p}<0.001)$. There was no significant relationship between age $(\mathrm{p}<0.745$, $0.070)$ and gender $(\mathrm{P}<0.177,0.115)$ of patient with BSL (Table 2$)$.

Normal BSL was significantly correlated with Diabetes knowledge, medication adherence and lower incidence of disease related complications $(\mathrm{P}<0.001)$ (Table 3$)$.

\begin{tabular}{|c|c|c|c|c|c|c|c|}
\hline $\begin{array}{l}\text { Variabl } \\
\text { es }\end{array}$ & $\begin{array}{l}\text { Freque } \\
\text { ncy } \\
n\end{array}$ & $\begin{array}{l}\text { Fasting } \\
\text { BSL } \\
\\
<100 \\
\mathrm{mg} / \mathrm{dl} \\
\mathrm{n}\end{array}$ & $\begin{array}{l}\text { Fasting } \\
\text { BSL } \\
\\
>100 \\
\mathrm{mg} / \mathrm{dl} \\
\mathrm{n}\end{array}$ & $\begin{array}{l}P \\
\text { value }\end{array}$ & $\begin{array}{l}\text { PP BSL } \\
<135 \mathrm{mg} / \\
\text { dl } \\
\mathrm{n}\end{array}$ & $\begin{array}{l}\mathrm{PP} \\
\mathrm{BSL} \\
\\
>135 \\
\mathrm{mg} / \mathrm{dl} \\
\mathrm{n}\end{array}$ & $\begin{array}{l}P \\
\text { value }\end{array}$ \\
\hline Age & & & & 0.745 & & & 0.07 \\
\hline $\begin{array}{l}40-50 \\
\text { yrs. }\end{array}$ & 27 & 10 & 17 & & 16 & 11 & \\
\hline
\end{tabular}

\begin{tabular}{|c|c|c|c|c|c|c|c|}
\hline $\begin{array}{l}51-60 \\
\text { yrs. }\end{array}$ & 36 & 11 & 25 & & 12 & 24 & \\
\hline $\begin{array}{l}61-70 \\
\text { yrs. }\end{array}$ & 29 & 12 & 17 & & 12 & 17 & \\
\hline$>70 \mathrm{yrs}$ & 8 & 2 & 6 & & 1 & 7 & \\
\hline Gender & & & & 0.177 & & & 0.115 \\
\hline Male & 54 & 26 & 28 & & 26 & 28 & \\
\hline Female & 46 & 16 & 30 & & 15 & 31 & \\
\hline $\begin{array}{l}\text { Educati } \\
\text { on }\end{array}$ & & & & $<0.001$ & & & $<0.001$ \\
\hline $\begin{array}{l}\text { No } \\
\text { formal }\end{array}$ & 12 & 2 & 10 & & 3 & 9 & \\
\hline Primary & 26 & 5 & 21 & & 3 & 23 & \\
\hline $\begin{array}{l}\text { Second } \\
\text { ary }\end{array}$ & 57 & 34 & 23 & & 31 & 26 & \\
\hline $\begin{array}{l}\text { Graduat } \\
\text { ion }\end{array}$ & 4 & 3 & 1 & & 4 & 0 & \\
\hline $\begin{array}{l}\text { Post } \\
\text { graduati } \\
\text { on }\end{array}$ & 1 & 0 & 1 & & 0 & 1 & \\
\hline
\end{tabular}

Table 2: Correlation between demographic variables with blood sugar levels $\left({ }^{*} \mathrm{p}<0.01\right.$ difference statistically significant, ${ }^{*} \mathrm{P}<0.001$ difference statistically highly significant) $n=$ number of patients

\begin{tabular}{|l|l|l|l|l|}
\hline & Frequency & $\begin{array}{l}\text { Adequate } \\
\text { Knowledge }\end{array}$ & $\begin{array}{l}\text { Better } \\
\text { adherence }\end{array}$ & $\begin{array}{l}\text { No } \\
\text { Complications }\end{array}$ \\
\hline Fasting BSL & & & & \\
\hline$<100 \mathrm{mg} / \mathrm{dl}$ & 42 & $39^{* *}$ & $42^{* *}$ & $41^{* *}$ \\
\hline$>100 \mathrm{mg} / \mathrm{dl}$ & 58 & 6 & 4 & 23 \\
\hline PP BSL & & & & \\
\hline$<135 \mathrm{mg} / \mathrm{dl}$ & 41 & $38^{\star *}$ & $40^{* *}$ & $40^{* *}$ \\
\hline$>135 \mathrm{mg} / \mathrm{dl}$ & 59 & 6 & 6 & 24 \\
\hline
\end{tabular}

Table 3a

\begin{tabular}{|l|l|l|l|l|}
\hline & Frequency & $\begin{array}{l}\text { Inadequate } \\
\text { Knowledge }\end{array}$ & $\begin{array}{l}\text { Poor } \\
\text { adherence }\end{array}$ & $\begin{array}{l}\text { Associated } \\
\text { Complications }\end{array}$ \\
\hline $\begin{array}{l}\text { Fasting } \\
\text { BSL }\end{array}$ & & & & \\
\hline$<100 \mathrm{mg} / \mathrm{dl}$ & 42 & 3 & 0 & 1 \\
\hline$>100 \mathrm{mg} / \mathrm{dl}$ & 58 & $52^{\star *}$ & $54^{\star *}$ & $35^{\star}$ \\
\hline PP BSL & & & & \\
\hline$<135 \mathrm{mg} / \mathrm{dl}$ & 41 & 3 & 1 & 1 \\
\hline$>135 \mathrm{mg} / \mathrm{dl}$ & 59 & $53^{\star \star}$ & $53^{\star *}$ & $35^{\star}$ \\
\hline
\end{tabular}

Table 3b 
Citation: Mandpe AS, Pandit VA, Dawane JS, Patel HR (2014) Correlation of Disease Knowledge with Adherence to Drug Therapy, Blood Sugar Levels and Complications Associated with Disease among Type 2 Diabetic Patients. J Diabetes Metab 5: 369. doi: $10.4172 / 2155-6156.1000369$

Page 4 of 5

Tables 3a and 3b: Correlation between blood sugar levels with diabetes knowledge, adherence to drug therapy and history of diabetes related complications. $\left({ }^{*} \mathrm{p}<0.01\right.$ difference statistically significant, ${ }^{* *} \mathrm{P}<0.001$ difference statistically highly significant) $\mathrm{n}=$ number of patients

There was a significant correlation between adequate knowledge about diabetes, better adherence with medication, better glycemic control and less incidence of disease related complications (Table 4).

\begin{tabular}{|l|l|l|l|l|l|}
\hline Variable & Frequency & $\begin{array}{l}\text { Better } \\
\text { Adherence }\end{array}$ & $\begin{array}{l}\text { F } \\
\text { BSL< } \\
100\end{array}$ & $\begin{array}{l}\text { PP } \\
\text { BSL } \\
<135\end{array}$ & $\begin{array}{l}\text { No } \\
\text { Complications }\end{array}$ \\
\hline $\begin{array}{l}\text { Adequate } \\
\text { knowledge }\end{array}$ & 45 & $42^{* *}$ & $39^{* *}$ & $38^{* *}$ & $44^{*}$ \\
\hline
\end{tabular}

\section{Table 4a}

\begin{tabular}{|l|l|l|l|l|l|}
\hline Variable & Frequency & $\begin{array}{l}\text { Poor } \\
\text { Adherence }\end{array}$ & $\begin{array}{l}\text { F } \\
\text { BSL }> \\
100\end{array}$ & $\begin{array}{l}\text { PP } \\
\text { BSL } \\
>135\end{array}$ & Complications \\
\hline $\begin{array}{l}\text { Inadequate } \\
\text { knowledge }\end{array}$ & 55 & $51^{* \star}$ & $52^{* \star}$ & $52^{* \star}$ & $35^{*}$ \\
\hline
\end{tabular}

\section{Table $4 \mathrm{~b}$}

Tables 4a and 4b: Correlation between diabetes knowledge, adherence to drug therapy, blood sugar levels and history of diabetes related complications. $\left({ }^{*} \mathrm{p}<0.01\right.$ difference statistically significant, ${ }^{* *} \mathrm{P}<0.001$ difference statistically highly significant) $\mathrm{n}=$ number of patients

\section{Discussion}

The WHO defines adherence to long-term therapy as "the extent to which a person's behaviour-taking medication, following a diet, and/or executing lifestyle changes-corresponds with agreed recommendations from a health care provider" [7].

As adherence is a key factor associated with the effectiveness of all pharmacological therapies and foremost important for medications prescribed for chronic conditions like diabetes. Of all medicationrelated hospitalizations that occur in the United States, between onethird and two-thirds are the result of poor medication adherence [21].

Poor adherence to medical treatment severely compromises patient outcomes and increases patient mortality. According to the WHO, improving adherence to medical therapy for conditions of hypertension, hyperlipidemia, and diabetes would yield very substantial health and economic benefits. Non-adherence to the medical regimen is a major clinical problem in the management of patients with chronic illness like diabetes [7].

The WHO classifies these factors into 5 categories: socioeconomic factors, factors associated with the health care team and system in place, disease-related factors, therapy-related factors, and patientrelated factors. In broader terms, these factors fall into the categories of patient-related factors, physician-related factors, and health system/ team building-related factors [7].

Long term drugs administration for many chronic illnesses and adherence to such treatment regimens often declines significantly over time. This often happens when patient have few or no symptoms and the absence of them is a barrier for people to take their medication. It is important for the patient to understand the illness and what will happen if it is not treated [22].

The present study is the one of the systematic study showing the significant correlation between knowledge about diabetes, adherence to drug therapy, better diabetic control and less incidence of diabetes related complications.

The main objective of this study was to evaluate the association of diabetes knowledge and medication adherence with glycemic control among patients with type 2 diabetes. The results revealed that glycemic control was associated with both variables. These findings were consistent with findings of study conducted at the Diabetes Outpatients Clinic, Hospital PulauPenan [17].

A low level of diabetes knowledge among patients with diabetes has been identified in other countries [23-29]. Previous studies had consistently reported that improving patients' knowledge might help attain the goals of diabetes management [30]. Several studies have shown that proper and adequate knowledge of diabetes was effectively associated with good diabetic control [30,31].

In present study, it was also found that as level of education increases, there is increase in diabetes knowledge. Patients with higher educational level might have more opportunity to obtain knowledge from the press, books and internet. In addition, they might have fewer barriers in communicating with healthcare providers. These findings were consistent with findings of study conducted at the Diabetes Outpatients Clinic, Hospital PulauPenan [17].

Patient education, understanding, and participation is vital, since the complications of diabetes are far less common and less severe in people who have well-managed blood sugar levels $[32,33]$.

Better diabetes knowledge provided better understanding about disease management. This was reflected by better adherence to medication, well control blood sugar levels and less incidence of disease related complications.

\section{Conclusion}

This study revealed that knowledge and adherence are among the modifiable factors that are associated with better glycemic control. Patients with higher knowledge showed better medication adherence and better glycemic control.

The findings from this study suggest that there is a need of educating patients about diabetes for better adherence to drug therapy and better glycemic control. In addition to other factors affecting medication adherence and glycemic control, healthcare providers play a key role in creating awareness about the low adherence and mortality in the community.

\section{References}

1. Shoback (2011) Greenspan's basic \& clinical endocrinology (9th ed.). New York: McGraw-Hill Medical.

2. Emerging Risk Factors Collaboration1, Sarwar N, Gao P, Seshasai SR, Gobin R, et al. (2010) Diabetes mellitus, fasting blood glucose concentration, and risk of vascular disease: a collaborative meta-analysis of 102 prospective studies. Lancet 375: 2215-2222.

3. Boussageon $\mathrm{R}$, Bejan-Angoulvant $\mathrm{T}$, Saadatian-Elahi $\mathrm{M}$, Lafont $\mathrm{S}$, Bergeonneau C, et al. (2011) Effect of intensive glucose lowering treatment on all cause mortality, cardiovascular death, and microvascular 
Citation: Mandpe AS, Pandit VA, Dawane JS, Patel HR (2014) Correlation of Disease Knowledge with Adherence to Drug Therapy, Blood Sugar Levels and Complications Associated with Disease among Type 2 Diabetic Patients. J Diabetes Metab 5: 369 . doi: $10.4172 / 2155-6156.1000369$

Page 5 of 5

events in type 2 diabetes: meta-analysis of randomised controlled trials. BMJ 343: d4169.

4. Wild S, Roglic G, Green A, Sicree R, King H (2004) Global prevalence of diabetes: estimates for the year 2000 and projections for 2030. Diabetes Care 27: 1047-1053

5. Diabetes in India.

6. Diabetes capital' tag a burden on India's heart.

7. Sabaté E (2003) Adherence to Long-Term Therapies: Evidence for Action. Geneva, Switzerland: World Health Organization.

8. Omole Moses Kayode, Ahwinahwi Ufuoma Shalomm \& Adeleye Jokotade (2012) Global Journal of Medical Research 12.

9. Funnell MM, Brown TL, Childs BP, Haas LB, Hosey GM, et al. (2007) National standards for diabetes self-management education. Diabetes Care 30: 1630-1637.

10. King H, Rewers M (1993) Global estimates for prevalence of diabetes mellitus and impaired glucose tolerance in adults. WHO Ad Hoc Diabetes Reporting Group. Diabetes Care 16: 157-177.

11. WHO (2003) Adherence to long term Therapies, Time for action. Geneva: World Health Organisation 221.

12. Helmrich SP, Ragland DR, Leung RW, Paffenbarger RS Jr (1991) Physical activity and reduced occurrence of non-insulin-dependent diabetes mellitus. N Engl J Med 325: 147-152.

13. E Vermeire, P Van Royen, S Coenen, J Wens, J Denekens (2003) The adherence of type 2 diabetes patients to their therapeutic regimens; a qualitative study from the patient's perspective; Pract Diab Int 20: 6 .

14. Rhee MK, Slocum W, Ziemer DC, Culler SD, Cook CB, et al. (2005) Patient adherence improves glycemic control. Diabetes Educ 31: 240-250.

15. Simpson SH, Eurich DT, Majumdar SR, Padwal RS, Tsuyuki RT, et al. (2006) A meta-analysis of the association between adherence to drug therapy and mortality. BMJ 333: 15.

16. Krapek K, King K, Warren SS, George KG, Caputo DA, et al. (2004) Medication adherence and associated hemoglobin A1c in type 2 diabetes. Ann Pharmacother 38: 1357-1362.

17. Al-Qazaz HK, Sulaiman SA, Hassali MA, Shafie AA, Sundram S, et al. (2011) Diabetes knowledge, medication adherence and glycemic control among patients with type 2 diabetes. Int J Clin Pharm 33: 1028-1035.

18. Fitzgerald JT, Funnell MM, Hess GE, Barr PA, Anderson RM, et al. (1998) The reliability and validity of a brief diabetes knowledge test. Diabetes Care 21: 706-710.

19. Morisky DE, Ang A, Krousel-Wood M, Ward HJ (2008) Predictive validity of a medication adherence measure in an outpatient setting. J Clin Hypertens (Greenwich) 10: 348-354.

20. Canadian Diabetes Association Clinical Practice Guidelines Expert Committee (2008) Canadian Diabetes Association 2008 clinical practice guidelines for the prevention and management of diabetes in Canada. Can J Diabetes 32: S1-S201.

21. Osterberg L, Blaschke T (2005) Adherence to medication. N Engl J Med 353: 487-497.

22. Antonia Kalogianni (2011) Factors affect in patient adherence to medication regimen. Health Science Journal 5: 157-158.

23. Murata GH, Shah JH, Adam KD, Wendel CS, Bokhari SU, et al. (2003) Factors affecting diabetes knowledge in Type 2 diabetic veterans. Diabetologia 46: 1170-1178.

24. Al Shafaee MA, Al-Shukaili S, Rizvi SG, Al Farsi Y, Khan MA, et al. (2008) Knowledge and perceptions of diabetes in a semi-urban Omani population. BMC Public Health 8: 249.

25. Bruce DG, Davis WA, Cull CA, Davis TM (2003) Diabetes education and knowledge in patients with type 2 diabetes from the community: the Fremantle Diabetes Study. J Diabetes Complications 17: 82-89.

26. McClean M, McElnay J, Andrews W (2001) The association of psychosocial and diabetes factors to diabetes knowledge. Int J Pharm Pract 9: R9.

27. Gunay T, Ulusel B, Velipasaoglu S, Unal B, Ucku R, et al. (2006) Factors affecting adult knowledge of diabetes in Narlidere Health District, Turkey. Acta Diabetol 43: 142-147.

28. Angeles-Llerenas A, Carbajal-Sa'nchez N, Allen B, Zamora-Mun oz S, Lazcano-Ponce E (2005) Gender, body mass index and sociodemographic variables associated with knowledge about type 2 diabetes mellitus among 13293 Mexican students. Acta Diabetol 42: 3645.

29. Murugesan N, Snehalatha C, Shobhana R, Roglic G, Ramachandran A (2007) Awareness about diabetes and its complications in the general and diabetic population in a city in southern India. Diabetes Res Clin Pract 77: 433-437.

30. Berikai P, Meyer PM, Kazlauskaite R, Savoy B, Kozik K, et al. (2007) Gain in Patients' Knowledge of Diabetes Management Targets Is Associated With Better Glycemic Control. Diabetes Care 30: 1587-1589.

31. Al-Adsani AM, Moussa MA, Al-Jasem LI, Abdella NA, Al-Hamad NM (2009) The level and determinants of diabetes knowledge in Kuwaiti adults with type 2 diabetes. Diabetes Metab 35: 121-128.

32. Nathan DM, Cleary PA, Backlund JY, Genuth SM, Lachin JM, et al. (2005) Intensive diabetes treatment and cardiovascular disease in patients with type 1 diabetes. N Engl J Med 353: 2643-2653.

33. (1995) The effect of intensive diabetes therapy on the development and progression of neuropathy. The Diabetes Control and Complications Trial Research Group. Ann Intern Med 122: 561-568. 